\title{
Expression of ZmLEA3, AOX2 and ZmPP2C genes in maize lines associated with tolerance to water deficit
}

\section{Expressão dos genes ZmLEA3, AOX2 E ZmPP2C em linhagens de milho associados à tolerância ao déficit hídrico}

\author{
Thaís Lima Marques ${ }^{1 *} \mathbb{D}$, Renzo Garcia Von Pinho ${ }^{2} \mathbb{D}$, Édila Vilela de Resende Von Pinho ${ }^{2}$, \\ Heloisa Oliveira dos Santosº
}

\author{
'Universidade Federal de Lavras/UFLA, Departamento de Biologia/DBI, Lavras, MG, Brasil \\ 2Universidade Federal de Lavras/UFLA, Departamento de Agricultura/DAG, Lavras, MG, Brasil \\ *Corresponding author: limamarques.thais@gmail.com \\ Received in September 20, 2019 and approved in October 22, 2019
}

\begin{abstract}
Knowing genes related to water deficit is a valuable tool to assist and accelerate the selection process of maize genotypes more adapted to drought conditions. Therefore, this work aimed to evaluate genes expression related to tolerance to water deficit in maize lines, using proteomic and transcriptomic analyses. Two lines previously classified as tolerant (91-T) and non-tolerant (57-NT) to low water availability were used. Dried seeds, ears tips, and seedlings (collected at three, five, and seven days after sowing) of the two maize lines (91-T and 57-NT) were used in proteomic analyses. Seedlings were subject to two contrasting water-availability conditions (70\% and $10 \%$ of the water retention capacity). The expression of catalase, peroxidase, and esterase enzymes and heat-resistant proteins were evaluated by electrophoresis. Dried seeds, ears tips, and seedlings (collected at seven days after sowing, subject to two contrasting water-availability conditions) of two maize lines (91-T and 57-NT) were used in the transcriptomic analyses. The expression of genes associated with tolerance to low water availability (ZmPP2C, ZmLEA3, and AOX2) was evaluated by the $q R T-P C R$ technique. Results revealed that catalase, peroxidase, and esterase enzymes had a higher expression on the ears tips of the 91-T line. The expression of catalase and esterase enzymes reduced in seven-day-old seedlings in the two lines analyzed. Heat-resistant proteins had greater activity on the dried seeds of the 91-T line. The AOX2 gene was identified as a potential marker for the selection of maize genotypes tolerant to water deficit.
\end{abstract}

Index terms: Zea mays; abiotic stress; electrophoresis; qRT-PCR.

\begin{abstract}
RESUMO
O conhecimento de genes relacionados ao déficit hídrico é uma importante ferramenta visando auxiliar e acelerar o processo de seleção de genótipos de milho mais adaptados às condições de seca. Diante disso, objetivou-se neste trabalho avaliar a expressão de genes relacionados à tolerância ao déficit hídrico em linhagens de milho, por meio das análises proteômicas e transcriptômicas. Para isso, foram utilizadas duas linhagens previamente classificadas como tolerante (91-T) e não tolerante (57-NT) a baixa disponibilidade hídrica. Para as análises proteômicas, utilizaram-se sementes secas, ponta de espigas e plântulas coletadas com três, cinco e sete dias após a semeadura, sendo as plântulas submetidas a duas condições contrastantes quanto a disponibilidade hídrica (70\% e 10\% da capacidade de retenção de água). Avaliou-se a expressão das enzimas catalase, peroxidase, esterase e das proteínas resistentes ao calor por meio da técnica de eletroforese. Sementes secas, ponta de espigas e plântulas (coletadas sete dias após a semeadura, submetidas a duas condições de disponibilidade hídrica) de duas linhagens de milho (91-T e 57-NT) foram utilizadas para as análises transcriptômicas. A expressão dos genes associados a tolerância a baixa disponibilidade hídrica (ZmLEA3, AOX2 and ZmPP2C) foi realizada pela técnica de $q R T-P C R$. Pode-se concluir que houve maior expressão em ponta de espigas na linhagem 91-T para as enzimas catalase, peroxidase e esterase. Para as enzimas catalase e esterase, as plântulas de sete dias de desenvolvimento apresentaram uma redução da expressão, nas duas linhagens analisadas. Maior atividade das proteínas resistentes ao calor ocorreu nas sementes secas da linhagem 91-T. Identificou-se o gene AOX2 como um potencial marcador para seleção de genótipos de milho tolerantes ao déficit hídrico.
\end{abstract}

Termos para indexação: Zea mays; estresse abiótico; eletroforese; qRT-PCR.

\section{INTRODUCTION}

Maize is a cereal of great economic importance worldwide and is cultivated in practically all Brazilian states. Owing to breeding programs, maize plants usually present good performance under different climatic conditions. However, the incidence of abiotic stresses in 
the growing area, such as low water availability, implies significant yield losses.

Maize plants, when subject to water deficit, accumulate reactive oxygen species (ROS), which provoke oxidative stress and affect the antioxidant enzyme defense system and lipid peroxidation (Choudhury et al., 2017). Plants protect their cells and subcellular compartments from the toxic effects caused by ROS using protective compounds and several antioxidant enzymes, such as superoxide dismutase, catalase, ascorbate peroxidase, glutathione reductase, peroxiredoxin, and polyphenol oxidase (Choudhury et al., 2017).

In enzymatic detoxification mechanisms, the superoxide dismutase enzyme acts as the first defense line against ROS by transforming superoxide into hydrogen peroxide (Ighodaro; Akinloye, 2018). The hydrogen peroxide produced by the superoxide dismutase enzyme can be converted to water and oxygen by the catalase enzyme, or to water, by the ascorbate peroxidase enzyme. Regarding the lipid metabolism, the esterase enzyme is a degradative enzyme that acts on ester hydrolysis reactions (Turner; Humphreys, 2018).

According to Ding et al. (2012), the increase in the tolerance to water deficit in plants by the induction of different antioxidant defense systems is regulated by the abscisic acid (ABA). Nevertheless, some stress-responsive genes are not regulated by the ABA; instead, they are regulated by other molecular mechanisms, indicating the existence of an ABA-independent pathway. Several studies have evaluated genes with potential to increase tolerance to water deficit in plants, such as the ZmLEA3 and $A O X$ genes (Liu et al., 2013; Pastore et al., 2007). The $A O X$ gene, according to Silva Neta et al. (2015), has been used as a functional marker to select plants resistant to abiotic stress, based on the transcriptomic analysis.

Therefore, this work aimed to evaluate the expression of genes associated with water deficit in maize lines using proteomic and transcriptomic analyses. Specifically, this study sought to define potential marker genes, aiming to anticipate the selection of maize genotypes tolerant to water deficit.

\section{MATERIAL AND METHODS}

The experiment was carried out at the Center for Scientific and Technological Development in Agriculture (Muquém Farm) and the Central Seed Laboratory of the Federal University of Lavras (UFLA), in the city of Lavras, MG, Brazil. An experimental field for seed multiplication of two maize lines granted by Genesseds Ltda., Lavras, MG,
Brazil, was installed. Among the lines used, the line 91-T has been previously classified as tolerant to water deficit, and line 57-NT classified as not tolerant to water deficit.

The field experiment used six plants per linear meter and 0.8 meters spacing between rows. Fertilization and other cultural and phytosanitary treatments were carried out according to the necessity of the crop. Selfpollination were performed manually, and seeds were manually collected when they reached $25 \%$ of water content. Maize ears were dried at $35{ }^{\circ} \mathrm{C}$ until reaching $13 \%$ of water content and subsequently threshed manually, treated with the fungicide VITAVAX-THIRAM 200 (300 ml per $100 \mathrm{~kg}$ of seeds), and analyzed for several aspects.

For proteomic analyses, seeds of the two lines were sown in a sand substrate with $10 \%$ and $70 \%$ of water retention capacity, corresponding to the water deficit and no water deficit treatments, respectively. Entire seedlings (radicle, shoot, and endosperm residue) were removed at three, five, and seven days after sowing.

Seeds were also sown in pots to grow and produce maize ears. Ears were protected with plastic bags before the stigma was emitted. From five to ten days after the stigmastyle emission, the tips of maize ears with approximately 3 to $5 \mathrm{~cm}$ in length were collected.

Therefore, the treatments used in proteomic analyses included dried seeds, ears tips, and seedlings (collected at three, five, and seven days after sowing) of two maize lines (91-T and 57-NT). Seedlings were subject to two contrasting water availability conditions: no water deficit (70\% water retention capacity) and water deficit ( $10 \%$ water retention capacity).

Seedlings, dried seeds, and ears tips were ground in the presence of PVP (Polyvinylpyrrolidone) and liquid nitrogen in a porcelain mortar placed on ice for the analysis of the expression of catalase, peroxidase, and esterase enzymes and heat-resistant proteins. Afterward, the samples were stored at $-86^{\circ} \mathrm{C}$ in a deep-freezer (Alfenas, 2006).

Catalase and esterase enzymes were extracted using the $0.2 \mathrm{M}$ Tris HCL buffer $\mathrm{pH} 8.0+0.1 \%$ mercaptoethanol. The peroxidase enzyme was extracted using the phosphate buffer $+0.1 \%$ mercaptoethanol, proportion of $250 \mu \mathrm{l}$ per $100 \mathrm{mg}$ of sample. The material was homogenized in a vortex and kept in the refrigerator overnight, followed by centrifugation at $14,000 \mathrm{rpm}$ for 30 minutes, at $4{ }^{\circ} \mathrm{C}$ (Alfenas, 2006).

The electrophoretic run was performed in a polyacrylamide gel system $(7.5 \%$ separating gel and $4.5 \%$ concentrating gel). The gel/electrode system used was the Tris-glycine $\mathrm{pH}$ 8.9. Afterward, $60 \mu \mathrm{l}$ of 
the samples' supernatant was applied to the gel. The electrophoretic run was performed at $120 \mathrm{~V}$ for 5 hours. Then, the gels were revealed according to Alfenas (2006), with modifications. Enzymes were quantified using the Image $J^{\circledR}$ software, in pixel2.

For the analysis of the heat-resistant proteins expression, the buffer solution $(50 \mathrm{mM}$ tris-HCL-7,5; $500 \mathrm{mM} \mathrm{NaCl} ; 5 \mathrm{mM} \mathrm{MgCl} 2 ; 1 \mathrm{mM}$ PMSF) was added to the macerated samples at a ratio of 1:10 (material weight: extraction buffer volume). The homogenates were centrifuged at $14,000 \mathrm{rpm}$ for 30 minutes at $4{ }^{\circ} \mathrm{C}$, and the supernatant was incubated in a water bath at $85^{\circ} \mathrm{C}$ for 15 minutes and then centrifuged again. The supernatant was poured into microtubes, and the pellet was discarded. Before the application to the gel, sample tubes containing $70 \mu \mathrm{l}$ extract $+40 \mu \mathrm{l}$ sample buffer solution $(2.5 \mathrm{ml}$ glycerol, $0.46 \mathrm{~g}$ SDS, $20 \mathrm{mg}$ Bromophenol blue, and the volume completed to $20 \mathrm{ml}$ with extraction buffer Tris $\mathrm{pH}$ 7.5) were placed in a bath with boiling water for 5 minutes (protocols contained in Alfenas, 2006).

Afterward, $60 \mu \mathrm{l}$ of the extract containing heatresistant proteins plus sample buffer were applied to SDS-PAGE polyacrylamide gel at $12.5 \%$ (separating gel) and 6\% (concentrating gel). The electrophoretic run was performed at $120 \mathrm{~V}$, and the gels were stained with Coomassie Blue at $0.05 \%$ for 12 hours and bleached in a $10 \%$ acetic acid solution (protocols contained in Alfenas, 2006). The protein was quantified using the Image $J^{\circledR}$ software, in pixel2.

Transcripts related to water deficit tolerance were evaluated using the qRT-PCR technique, which was divided into four steps: RNA extraction and purification, reverse transcription for cDNA synthesis, real-time PCR, and analysis of results.
To this end, dried seeds, ears tips, and seedlings (seven-day-old) of two maize lines (91-T and 57-NT) were used. Seedlings were subject to two contrasting water availability conditions, no water deficit $(70 \%$ water retention capacity) and water deficit ( $10 \%$ water retention capacity).

For RNA extraction, samples were macerated in liquid nitrogen. Then, the Pure Link RNA Plant ${ }^{\circledR}$ (Invitrogen) reagent was added, following the manufacturer specifications. The RNA integrity was verified on $1 \%$ agarose gel (stained with GelRed, Biotium) and quantified in a spectrophotometer at wavelengths of 260 and $280 \mathrm{~nm}$.

After nucleic acids extraction, the samples were treated with DNAse. The KitDNAse Turbo Free ${ }^{\circledR}$ AMBIOM was used following the manufacturer recommendation. To verify the efficiency of the DNAse treatment, a conventional PCR was performed with all the samples, proving the non-amplification of the DNA.

After extraction and purification, the mRNA was employed as templates for cDNA synthesis, using the High Capacity DNA Reverse Transcription $\mathrm{cDNA}^{\circledR}$ kit from Applied Biosystems, following the manufacturer's protocol.

For the analysis of gene expression by the qRT-PCR technique, the target genes were chosen based on a previous literature review, considering their importance in studies on maize genotypes tolerant to water deficit. Gene sequences were searched on the maize genome database. Based on these sequences, primers were designed using the Primer Express 3.0 software (Applied Biosystems) (Table 1).

The analysis of the selected genes expression was performed in the ABI PRISM 7500 Real-Time PCR (Applied Biosystems) device, with the SYBR Green detection method. The thermal conditions of the reaction were 2 minutes at $50^{\circ} \mathrm{C}, 10$ minutes at $95^{\circ} \mathrm{C}$, followed by 40 cycles of 15 seconds at $95^{\circ} \mathrm{C}$ and 1 minute at $60^{\circ} \mathrm{C}$,

Table 1: Primers used in the $q R T-P C R$ analysis.

\begin{tabular}{|c|c|c|c|}
\hline Gene & Function & Sequence $\left(5^{\prime}-3^{\prime}\right)$ & Reference \\
\hline$Z m P P 2 C$ & $\begin{array}{l}\text { Abiotic stress resistance } \\
\text { regulator }\end{array}$ & $\begin{array}{l}\text { F: GGAAGCTCCGATAACATCACAGT } \\
\text { R: TCTTTGTCGTCGCCTGATTTC }\end{array}$ & Liu et al. (2013) \\
\hline$Z m L E A 3$ & $\begin{array}{l}\text { Osmoprotectants } \\
\text { biosynthesis }\end{array}$ & $\begin{array}{l}\text { F: CCACGAGACCACCTACAACT } \\
\text { R: CCTTTCTGGAGGAGCAAC }\end{array}$ & Liu et al. (2013) \\
\hline$A O X 2$ & $\begin{array}{l}\text { Alternative route of } \\
\text { respiration/antioxidant }\end{array}$ & $\begin{array}{l}\text { F: CCAAGACGCTGATGGATAAGG } \\
\text { R: AGCCATACCGCCTCTGGAA }\end{array}$ & $\begin{array}{l}\text { Pastore et al. (2007); Silva } \\
\text { Neta et al. (2015) }\end{array}$ \\
\hline$U B I$ & Reference gene & $\begin{array}{l}\text { F: AAGGCCAAGATCCAGGACAA } \\
\text { R: TTGCTTTCCAGCGAAGATGA }\end{array}$ & Silva Neta et al. (2015) \\
\hline Bact & Reference gene & $\begin{array}{l}\text { F: TGTCCATCACTTGTGGAAGCCTCCT } \\
\text { R:ACGACCTTAGCCAATATCGCACCA }\end{array}$ & Hu et al. (2011) \\
\hline
\end{tabular}

(F) sequence of the forward primer and $(R)$ sequence of the reverse primer. 
ending with 15 seconds at $95^{\circ} \mathrm{C}$. At the end of the cycles, a denaturation curve of $60-95{ }^{\circ} \mathrm{C}$ showed the specificity of the PCR reaction. Data were collected and stored in the 7500 Fast software (Version 2.1). For each reaction, $1.0 \mu \mathrm{l}$ cDNA (diluted 1: 5), $0.4 \mu \mathrm{l}$ of the forward primer/reverse primer $(10 \mu \mathrm{M}), 5 \mu \mathrm{l}$ MasterMixSYBR green (Applied Biosystems), and $3.6 \mu \mathrm{l}$ ultrapure water were used for a final volume of $10.0 \mu \mathrm{l} / \mathrm{sample}$. Negative controls and melting curves were included in all analyses.

Three biological replications were used in three technical replicates for each gene under study. Results were normalized by the Threshold Cycle $(\mathrm{Ct})$ obtained by the expression of the reference genes ubiquitin (UBI) and beta-actin $(\beta A C T)$. The $\mathrm{Ct}$ was determined by the number of cycles in which the fluorescence generated within a reaction crossed the threshold. Thus, a validation experiment was performed to prove that the amplification efficiencies of the target and reference genes were similar and very close to $100 \%$, allowing the definition of the best cDNA dilution used in each reaction (dilution 1:5). Samples with the lowest expression for each gene were used as calibration samples, and the relative expression was analyzed by the mathematical model proposed by Pfaffl (2001).

\section{RESULTS AND DISCUSSION}

Water deficit-tolerance in plants is a complex characteristic associated with several factors, such as the antioxidant enzyme expression. Under biotic and abiotic stress conditions, plants accumulate reactive oxygen species (ROS), which damage the DNA, proteins, and lipids (Choudhury et al., 2017). Under low water availability conditions, antioxidant enzymes play an important role in removing ROS from plants cells and subcellular compartments (Sofo et al., 2015). The catalase enzyme, for instance, converts hydrogen peroxide $\left(\mathrm{H}_{2} \mathrm{O}_{2}\right)$ to water $\left(\mathrm{H}_{2} \mathrm{O}\right)$ and protects cells from the oxidation caused by free radicals (Ighodaro; Akinloye, 2018).

Figure 1 represents the activity of the catalase enzyme. The highest expression was observed in dried seeds when compared to that observed in ears tips for the two lines tested (91-T and 57-NT). Line 91-T had higher expression in dried seeds and ears tips than line 57-NT.

The evaluation of the enzyme expression in seedlings with different development days revealed a reduction in the catalase expression in seven-day-old seedlings of both lines, evidencing the greater enzyme activity at the initial stages of seedling development. A similar result was reported by Zhang and Kirkham (1994), where the catalase enzyme activity in most wheat species analyzed increased or remained constant and subsequently decreased with longer exposure time to water deficit.

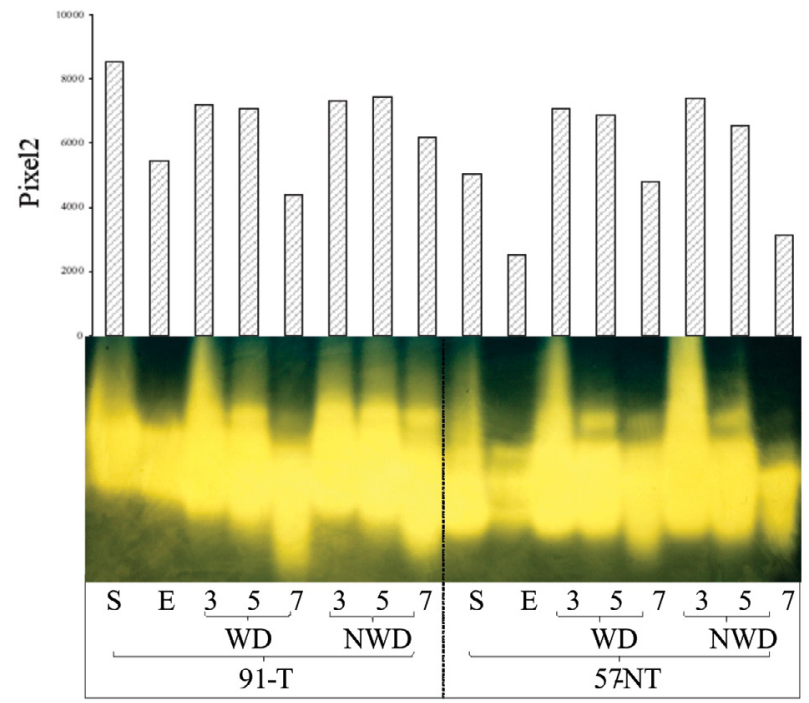

Figure 1: Catalase enzyme expression in dried seeds (S), ears tips (E), three-(3), five-(5), and seven (7) dayold seedlings under two water availability conditions [water deficit WD (10\% of water retention capacity and no water deficit NWD (70\% of water retention capacity)] of two maize lines (91-T and 57-NT).

The catalase enzyme expression was more uniform comparing the seedlings under both water availability conditions, with more alteration in the expression of both lines with seven-day-old. Catalase expression in seven-day-old seedlings of the non-tolerant line (57-NT) was higher for the seedlings developed in water deficit condition comparing with the seedlings developed in no water deficit. Conversely, the enzyme expression reduced in the seven-day-old seedling of the tolerant line (91-T) developed in low water availability.

Similar to the catalase enzyme, the peroxidase enzyme protects the cells from oxidation caused by free radicals. Greater peroxidase activity was observed in the ears tips when compared to the dried seeds, for both lines evaluated. The 57-NT line showed the highest expression for dried seeds, and the 91-T line showed the highest expression for ears tips (Figure 2).

The peroxidase enzyme expression is reduced in three-day-old seedlings when compared with five and sevenday-old seedlings. The increase in the peroxidase activity in the five- and seven-day-old seedlings can be explained by the high metabolic activity due to greater respiration, which implies the production of free radicals and consequently increases the activity of antioxidant enzymes, such as peroxidase (Silva Neta et al., 2015). When considering the isoforms with lower molecular weights, a higher expression 
of this enzyme was detected in five- and seven-day-old seedlings and in ears tips of the 91-T line when compared with that detected for the 57-NT line.

As observed for the catalase enzyme, the peroxidase enzyme expressions did not increase in the 91-T seedlings developed under water deficit conditions when compared with those developed under no water deficit conditions. However, for the 57-NT line, higher peroxidase enzyme expression occurred in seven-day-old seedlings developed in conditions under low water availability. A similar result was reported by El-Tayeb (2006), who evaluated the peroxidase expression in leaves of two cultivars of Vicia faba (Giza 40, tolerant to water deficit; and Giza 667, nontolerant to water deficit). The author detected an increase in the peroxidase enzyme expression only in non-tolerant cultivars subject to water deficit conditions.

In general, greater activity of catalase and peroxidase enzymes was detected for the 91-T line. Zhu (2002) states that high tolerance to low water-availability in plants is related to an increase in the enzymatic activity, corroborating the present results.

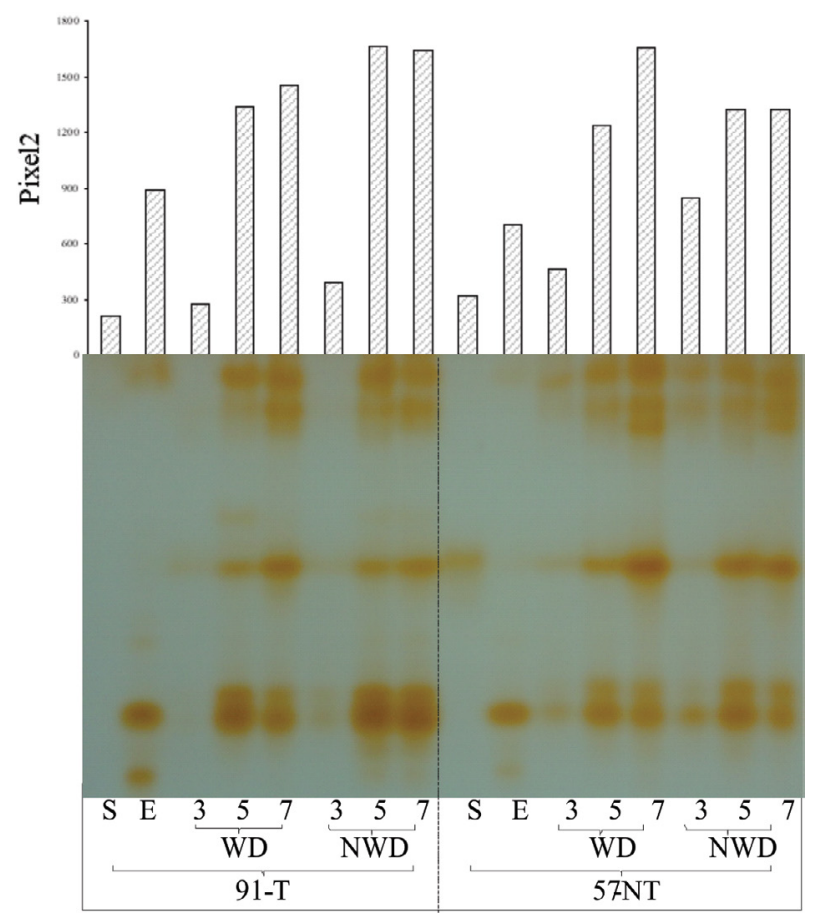

Figure 2: Peroxidase enzyme expression in dried seeds (S), ears tips (E), three- (3), five- (5), and seven- (7) dayold seedlings under two water availability conditions [water deficit WD (10\% water retention capacity) and no water deficit NWD (70\% water retention capacity)] of two maize lines (91-T and 57-NT).
The esterase enzyme is directly related to lipid metabolism. This is a degradative enzyme involved in esters hydrolysis reactions. Figure 3 shows the higher expression of the esterase enzyme in dried seeds of the 57-NT line when compared with those of the 91-T line.

The esterase enzyme activity was greater in the threeand five-day-old seedlings of both lines, regardless of the water availability condition. This result evidences a higher esterase enzyme expression at the initial stages of seedling development.

For both lines, no differences were observed for seedlings developed under water deficit and no water deficit conditions. This result means that the water stress did not alter the esterase enzyme expression for both lines analyzed. The zymogram (Figure 3 ) evidences the larger number of esterase isoforms in the non-tolerant line (57-NT), showing a higher enzyme expression in the non-tolerant comparing with the tolerant line.

The heat-resistant proteins are involved in the desiccation tolerance. They are expressed during seed development, accumulating at the end of the physiological maturity (Abreu et al., 2016). No significant polymorphisms were detected in the zymogram of the heat-resistant proteins (Figure 4). These proteins had greater activity in the dried seeds of the 91-T line when compared with those of the 57NT line. Abreu et al. (2016) also observed greater expression of heat-resistant proteins in 91 line.

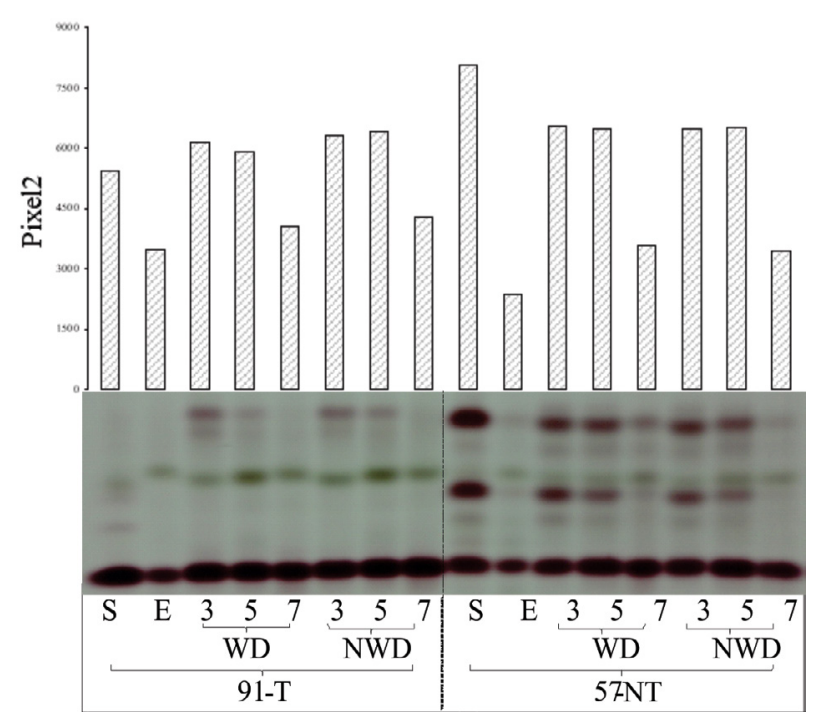

Figure 3: Esterase enzyme expression in dried seeds (S), ears tips (E), three- (3), five- (5), and seven- (7) dayold seedlings under two water availability conditions [water deficit WD (10\% water retention capacity) and no water deficit NWD (70\% water retention capacity)] of two maize lines (91-T and 57-NT). 


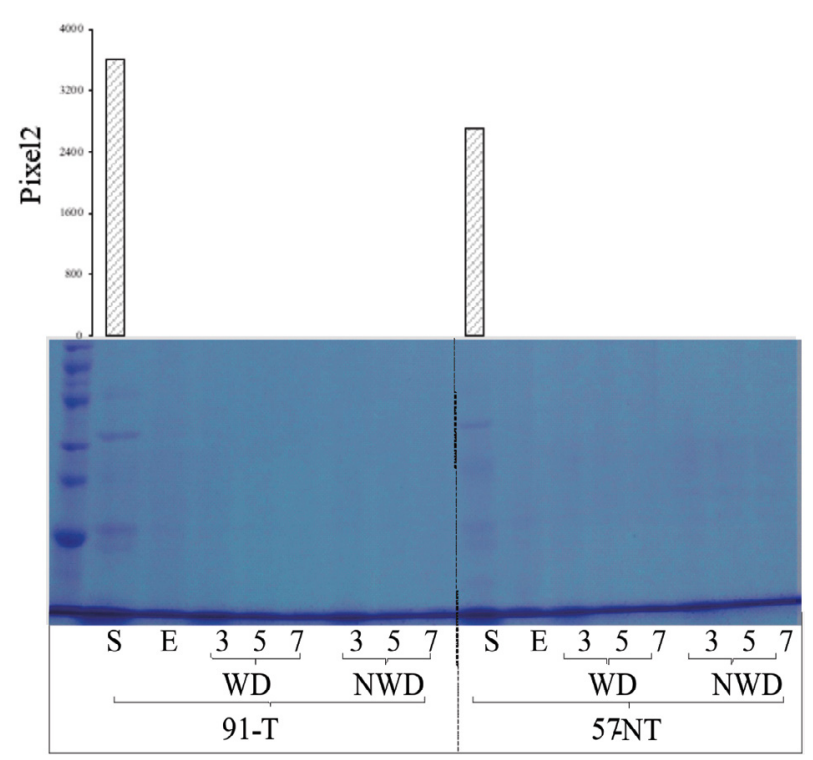

Figure 4: Heat-resistant proteins expression in dried seeds (S), ears tips (E), three- (3), five- (5), and seven(7) day-old seedlings under two water availability conditions [water deficit ( $10 \%$ water retention capacity) and no water deficit (70\% water retention capacity)] of two maize lines (91-T and 57-NT).

Heat-resistant proteins are responsible for the protection and stabilization of the cell membrane. An important relation between the heat-resistant proteins expression and the physiological quality of the seeds has been reported (Abreu et al., 2016; Silva Neta et al., 2015).

Considering the analysis of transcript expression in dried seeds, ears tips, and seedlings (cultivated under water deficit and no water deficit conditions) the results revealed a great variation in the activity of the genes of the different treatments evaluated (Figure 5).

Figure 5 shows the relative expression of $Z m L E A 3$, $A O X 2$ and $Z M P P 2 C$ gene. For the $Z m L E A 3$ gene higher expression was observed in ears tips of the 57-NT line. In general for the 91-T line, the different treatments presented low expression; just in ears tips the expression was higher. $Z m L E A 3$ gene had higher expression in seedlings developed under water deficit conditions than the seedling developed under no water deficit, for both lines. This phenomenon occurred because plants under drought conditions are subject to greater oxidative stress. These results corroborated those reported by Liu et al. (2013), in which overexpression of $Z m L E A 3$ gene in tobacco occurred to increase the plant tolerance to osmotic and oxidative stress.
Figure 5 also shows the relative expression of the alternative oxidase 2 gene $(A O X 2)$. According to Silva Neta et al. (2015), $A O X$ gene has been an important functional marker in the selection of abiotic stress-tolerant plants, such as $A O X 1$ gene, presenting great potential as a good marker in the selection of genotypes tolerant to low temperatures. Dried seeds and ears tips presented lower $A O X 2$ gene expression that the seedlings for the two lines under study. Highest expression in dried seeds and ears tips was detected in the line 91-T and 57-NT, respectively. Seedlings of 57-NT line presented lower expression when compared with those of 91-T line.

Unlike the 57-NT line, the expression in the seedlings was higher in seedlings developed under water deficit conditions, where the effects of reactive oxygen species (ROS) are more pronounced. According to Pastore et al. (2007), AOX gene can protect plants subject to biotic and abiotic stress conditions by reducing the ROS formation in plants.

Therefore, the higher gene expression in seedlings of the tolerant line developed under low water availability conditions suggests that $A O X 2$ gene is activated under abiotic stress, such as water deficit, to combat the oxidative stress, acting as an antioxidant defense system (Pastore et al., 2007). The fact that $A O X 2$ gene has higher expression in seedlings of tolerant line reveals that this gene has significant potential as a good marker in the early selection of genotypes tolerant to low water availability.

Regarding the $Z m P P 2 C$ gene, higher expression was observed in the ears tip of 57-NT line. Seedlings of 57-NT line developed under water deficit condition, which triggers the greater accumulation of toxic substances caused by reactive oxygen species (ROS), presented greater activity of the $\mathrm{ZmPP} 2 \mathrm{C}$ gene in relation to those developed with no water deficit.

For 91-T line, $Z m P P 2 C$ gene expression was higher in dried seeds, followed by seedlings developed under water deficit and no water deficit conditions. However, ears tips presented a lower gene expression. In relation to dried seeds and ears tip, higher expression was detected in non-tolerant line (57-NT) than in tolerant line (91-T). Liu et al. (2009) evaluated the $Z m P P 2 C$ gene expression in plants and observed that the overexpression of the gene reduces plant tolerance to water deficit. This phenomenon can be observed in figure $5 \mathrm{C}$, where higher $\mathrm{ZmPP} 2 \mathrm{C}$ gene expression is reported for 57-NT line. 

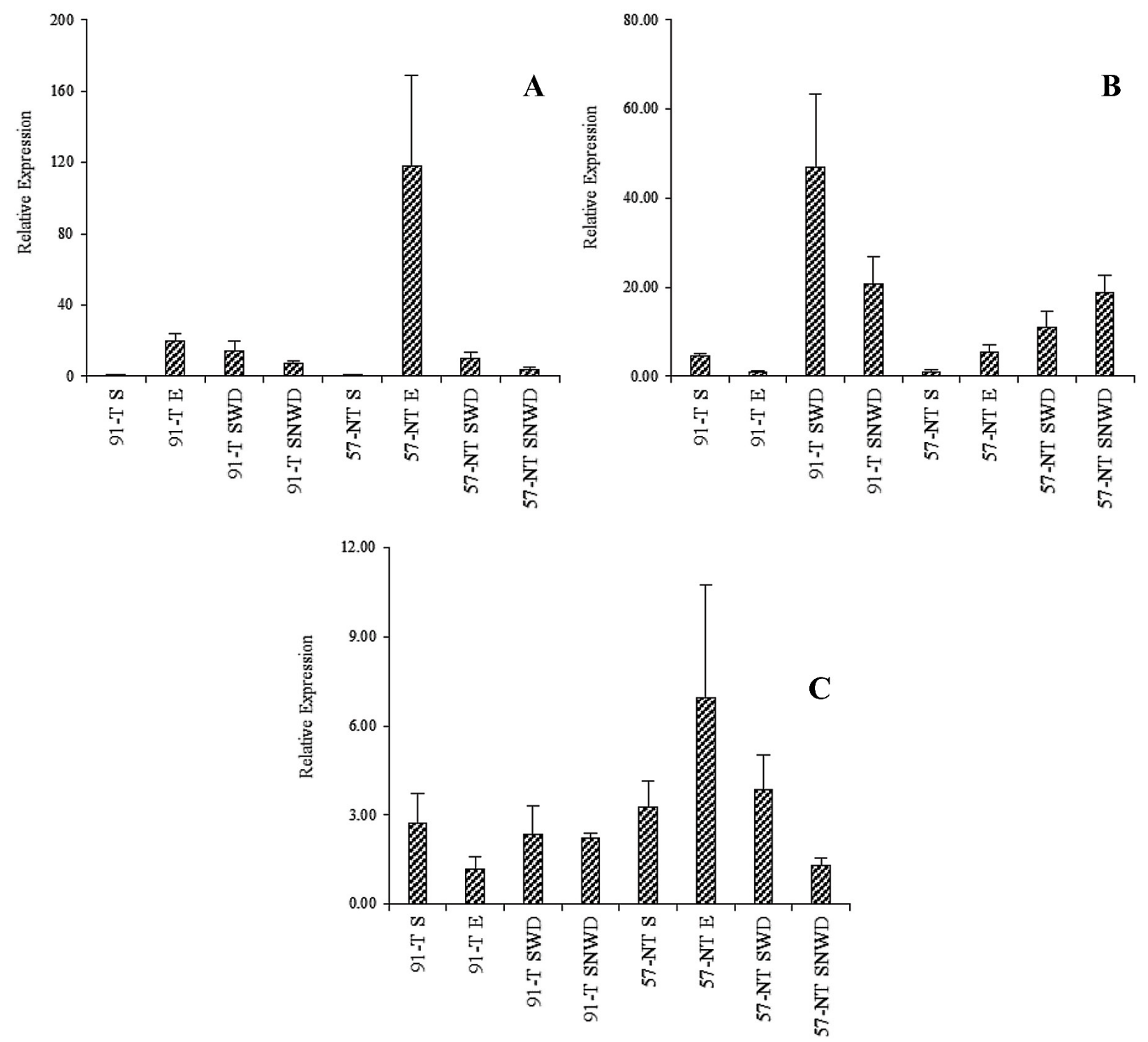

Figure 5: Expression of the genes $Z m L E A 3(\mathrm{~A}), A O X 2(\mathrm{~B}), Z m P P 2 C(\mathrm{C})$ in the dried seeds (S), ears tips (E) and seedlings of two maize lines (91-T and 57-NT) under two water availability conditions, seedlings water deficit (SWD) (10\% water retention capacity of substrate) and seedlings no water deficit (SNWD) (70\% water retention capacity of substrate).

Results of the proteomic analyses evidence the necessity of studies on enzymatic activities and reinforce the complexity involved in tolerance to water deficit. The evaluation of the transcriptomic expression enables accelerating the selection of materials with traits of interest. Therefore, it becomes an essential tool due to the small space and little work and time required, serving as functional markers in selection of genotypes tolerant to water deficit, such as $A O X 2$ gene evaluated in this work.

\section{CONCLUSIONS}

Ears tips of 91-T line presented higher expression of catalase, peroxidase, and esterase enzymes. For catalase and esterase enzymes, seven-day-old seedlings had lower expression for the two lines analyzed. Heat-resistant proteins presented greater activity in dried seeds of 91-T line. $A O X 2$ gene was identified as a potential marker for the selection of maize genotypes tolerant to water deficit. 


\section{ACKNOWLEDGMENTS}

Financial support was provided by the Coordination of Improvement of Higher Education Personnel (CAPES) Foundation and the National Council of Scientific and Technological Development (CNPq).

\section{REFERENCES}

ABREU, V. M. et al. Heat-resistant protein expression during germination of maize seeds under water stress. Genetics and Molecular Research, 15(3):1-9, 2016.

ALFENAS, A. C. Eletroforese de isoenzimas e proteínas afins: Fundamentos e aplicações em plantas e microorganismos. Viçosa: Editora UFV, 2006. 574p.

CHOUDHURY, F. K. et al. Reactive oxygen species, abiotic stress and stress combination. The Plant Journal, 90(5):856-867, 2017.

DING, Y. et al. ZmCPK11 is involved in abscisic acid-induced antioxidant defence and functions upstream of ZmMPK5 in abscisic acid signalling in maize. Journal of Experimental Botany, 64(4):871-884, 2012.

EL-TAYEB, M. A. Differential response of two Vicia faba cultivars to drought: Growth, pigments, lipid peroxidation, organic solutes, catalase and peroxidase activity. Acta Agronomica Hungarica, 54(1):25-37, 2006.

$\mathrm{HU}, \mathrm{Y}$. et al. Trichostatin a selectively suppresses the coldInduced transcription of the ZmDREB1 gene in maize. PLoS ONE, 6(7):1-13, 2011.

IGHODARO, O. M.; AKINLOYE, O. A. First line defence antioxidants-superoxide dismutase (SOD), catalase (CAT) and glutathione peroxidase (GPX): Their fundamental role in the entire antioxidant defence grid. Alexandria Journal of Medicine, 54(4):287-293, 2018.

LIU, S. et al. Genome-wide analysis of ZmDREB genes and their association with natural variation in drought tolerance at seedling stage of Zea mays L. PLoS Genetics, 9(9):1-17, 2013.

LIU, L. et al. Over-expression of a Zea mays L. protein phosphatase $2 \mathrm{C}$ gene ( $\mathrm{ZmPP} 2 \mathrm{C}$ ) in Arabidopsis thaliana decreases tolerance to salt and drought. Journal of Plant Physiology, 166(5): 531-542, 2009.

PASTORE, D. et al. Possible plant mitochondria involvement in cell adaptation to drought stress. Journal of Experimental Botany, 58(2):195-210, 2007.

PFAFFL, M. W. A new mathematical model for relative quantification in real-time RT-PCR. Nucleic Acids Research, 29(9):2002-2007, 2001.

SILVA NETA, I. C. et al. Expression of genes related to tolerance to low temperature for maize seed germination. Genetics and Molecular Research, 14(1):2674-2690, 2015.

SOFO, A. et al. Ascorbate peroxidase and catalase activities and their genetic regulation in plants subjected to drought and salinity stresses. International Journal of Molecular Sciences, 16(6):13561-13578, 2015.

TURNER, N. J.; HUMPHREYS, L. Biocatalysis in organic synthesis: The retrosynthesis approach. CPI Group, 2018. 29p.

ZHANG, J.; KIRKHAM, M. B. Drought-stress-induced changes in activities of superoxide dismutase, catalase, and peroxidase in wheat species. Plant Cell Physiology, 35(5):785-791, 1994.

ZHU, J. K. Salt and drought stress signal transduction in plants. Annual Review of Plant Biology, 53(1):247-273, 2002. 